\title{
Ovarian intratumoral 21-hydroxylase deficiency in a postmenopausal hirsute woman
}

\author{
Deficiência de 21-hidroxilase ovariana intratumoral \\ na virilização da mulher pós-menopausa
}

Selma B. Souto',2, Pedro V. Baptista ${ }^{3}$, Filomena Barreto 4 , Pedro F. Sousa ${ }^{5}$, Daniel C. Braga',2, Davide Carvalho',2

'Department of Endocrinology, Diabetes and Metabolism, Centro Hospitalar São João, Porto, Portugal 2 University of Porto, School of Medicine, Porto, Portugal

${ }^{3}$ Department of Gynaecology and Obstetrics, Centro Hospitalar São João, Porto, Portugal ${ }^{4}$ Department of Pathology, Centro Hospitalar São João, Porto, Portugal ${ }^{5}$ Department of Radiology, Centro Hospitalar São João, Porto, Portugal

\section{SUMMARY}

Virilising ovarian tumours are a rare cause of hyperandrogenism in women, accounting for less than $5 \%$ of all ovarian neoplasms. It occurs most often in - and postmenopausal women. We report a case of a 64 year-old woman with signs of virilisation that had started 3 years before. Blood hormone analysis revealed increased levels of testosterone, and 17-hydroxyprogesterone. The tetracosactin test revealed 21-hydroxylase deficiency. Radiological imaging demonstrated a nodule in her left ovary. The patient was submitted to bilateral laparoscopic oophorectomy, and histopathological examination revealed a luteoma of the left ovary. Postoperative serum testosterone level and 17-hydroxyprogesterone returned to normal levels in one month. Virilism regressed within six months. Our patient also showed an elevation in 17-OHP serum levels. Normalization of 17-OHP after oophorectomy suggests a case of intratumoral 21-hydroxylase deficiency. To our knowledge, this is the first description of ovarian intratumoral 21-hydroxylase deficiency in a postmenopausal woman. Arq Bras Endocrinol Metab. 2012;56(9):672-6

\section{SUMÁRIO}

Correspondence to:

Selma B. Souto

Department of Endocrinology,

Diabetes and Metabolism,

Centro Hospitalar São João,

Porto, Portugal

School of Medicine

University of Porto, Portugal

Alameda Prof. Hernâni Monteiro

4200-319 - Porto, Portugal

sbsouto.md@mail.com

Received on Jan/10/2012

Accepted on Mar/16/2012
Tumores ovarianos virilizantes são uma causa rara de hiperandrogenismo em mulheres, contabilizando menos de $5 \%$ de todos as neoplasias ovarianas. Esses tumores ocorrem mais comumente em mulheres em peri ou pós-menopausa. Relatamos aqui o caso de uma mulher de 64 anos de idade com sintomas de virilização que começaram 3 anos antes. 0 perfil hormonal revelou níveis aumentados de testosterona e de 17-hidroxiprogesterona (17-OHP). 0 teste de tetracosactin demonstrou deficiência de 21-hidroxilase. Exames radiológicos mostraram um nódulo no ovário esquerdo. A paciente foi submetida à ooforectomia laparoscópica bilateral e o exame histopatológico revelou um luteoma no ovário esquerdo. A concentração sérica de testosterona e de 17-hidroxiprogesterona após a cirurgia retornou aos níveis normais em um mês. A virilização regrediu em 6 meses. Nossa paciente também revelou uma elevação dos níveis séricos de 17-OHP. A normalização da 17-OHP após a ooforectomia sugere um caso de deficiência de 21-hidroxilase intratumoral. Esta é a primeira descrição de deficiência de 21-hidroxilase intratumoral em uma mulher na pós-menopausa. Arq Bras Endocrinol Metab. 2012;56(9):672-6

\section{INTRODUCTION}

$\mathrm{V}$ irilising ovarian tumours are a rare cause of hyperandrogenism in women, accounting for less than $5 \%$ of all ovarian neoplasms, and those that are malignant, for less than $10 \%$ of all ovarian cancers (1). It occurs most often in peri- and postmenopausal women (2).

The spectrum of ovarian neoplasms covers an extremely wide range of tumours. The best recognized ones are surface epithelial cell tumours. Among the less common variants, lipid or steroid cell tumours comprise an important category, despite accounting for only $0.1 \%$ of all ovarian tumours $(3)$.

Steroid cell tumours have been subclassified as stromal luteomas, Leydig cell tumours, and steroid cell tumours not otherwise specified (NOS) (4). Stromal luteoma was first described by Scully in 1964. The tu- 
mour occurs in postmenopausal women in $80 \%$ of cases; estrogenic manifestations occur in $60 \%$ of patients, and only $12 \%$ of tumours are androgenic. Stromal luteoma accounts for approximately $20 \%$ of all ovarian steroid cell tumours, and is characterized by a location within the ovarian stroma and absence of Reinke's crystals. Tumours are small, almost always $<3 \mathrm{~cm}$ in diameter, solid, circumscribed, and centred in the ovary proper. They are usually grayish white or yellow but may have red or brown areas. They are composed of large polygonal lutein-type cells that proliferate diffusely or are arranged in cords or nests. Mitoses are uncommon. Nodules composed entirely of lutein cells that are $1 \mathrm{~cm}$ or larger are arbitrarily classified as stromal luteomas, whereas smaller nodules are considered to be stromal hyperthecosis.

In most cases, hormonal abnormalities found in patients with virilising ovarian tumours include increased serum testosterone levels in the presence of normal levels of serum dehydroepiandrosterone-sulfate (DHEA-S) (5).

This paper focuses on a case of a virilising ovarian tumour diagnosed in a 64-year-old postmenopausal woman. The patient was found to have a steroid-cell ovarian tumour, stromal luteoma type, which proved to be the aetiology of the virilisation in this patient.

\section{CASE REPORT}

A 64-year-old married woman, Jehovah's witness, who complained of progressive hirsutism, was sent to the Endocrinology Department. She had a history of essential hypertension, obesity, primary infertility, and obstructive sleep apnoea. She was medicated with lisinopril $5 \mathrm{mg} /$ day and simvastatin $20 \mathrm{mg}$ /day.

She reported hirsutism for three years, initially involving the face, and later her back and abdomen. In the six months before the appointment, she developed androgenetic alopecia, worsening of hirsutism, breast atrophy and deepening of the voice. She did not have vaginal bleeding or systemic symptoms. Familial clinical history was irrelevant.

Physical examination showed hirsutism of the face, back and abdominal area (score $>8$, Ferriman-Gallwey scale). Gynaecological examination was normal, without adnexal masses or enlargement of the clitoris. Blood pressure was $120 / 80 \mathrm{mmHg}$. She had no features of Cushing syndrome. Haemoglobin, haematocrit, fasting plasma glucose, serum electrolytes, cholesterol, triglycerides, calcium, phosphorus, renal and liver function were normal. Endocrine evaluation revealed hyperandrogenism, with a marked increase in total serum testosterone concentration $(4.55 \mathrm{ng} / \mathrm{mL})$, while concentrations of DHEA-S and delta 4 -androstenedione were within the normal range (Table 1). She also had high serum levels of 17-hydroxyprogesterone $(17 \mathrm{OHP})(3.42 \mathrm{ng} / \mathrm{mL})$. Serum prolactin and thyroid stimulating hormone (TSH) were within the normal range. Serum luteinizing hormone $(\mathrm{LH})$, follicle stimulating hormone (FSH), and estradiol concentrations were within the normal range for menopause. Normal urinary cortisol levels ruled out subclinical hypercortisolism. Tetracosactin test was performed, pointing out a deficiency in 21-hydroxylase (Table 2).

Transvaginal ultrasound suggested a vascularised node in the stroma of the left ovary. The other ovary was normal; endometrial stripe was linear and there was no fluid in the peritoneal cavity. The pelvic and abdominal computerized axial tomography (CT) (Figure 1), showed a solid nodule in the left ovary with $16 \mathrm{~mm}$ in diameter, and morpho-dimensional normality of the adrenal glands. No other pathological findings were detected, namely, ascites or lymph node enlargement. Magnetic resonance imaging (MRI) was also performed, confirming the left ovarian solid nodule (Figure 2).

Table 1. Laboratory evaluation before surgery, and two months after surgery

\begin{tabular}{lccc}
\hline & Before & After & Reference values \\
\hline Free testosterone & 8.17 & 0.82 & $<0.15-1.55 \mathrm{pg} / \mathrm{mL}$ \\
Total testosterone & 4.55 & 0.20 & $0.11-0.78 \mathrm{ng} / \mathrm{mL}$ \\
DHEA-S & 84.2 & 55.2 & $35-110 \mu \mathrm{g} / \mathrm{dL}$ \\
Delta 4 - androstenedione & 2.1 & 1.31 & $0.30-2.99 \mathrm{ng} / \mathrm{mL}$ \\
$17-\mathrm{OHP}$ & 3.42 & 0.44 & $0.11-1.20 \mathrm{ng} / \mathrm{mL}$ \\
FSH & 26 & & $25.8-150.3 \mathrm{mUl} / \mathrm{mL}$ \\
LH & 16 & & $10.4-64.6 \mathrm{mUl} / \mathrm{mL}$ \\
Estradiol & 40 & & $<5-54.7 \mathrm{pg} / \mathrm{mL}$ \\
Prolactin & 11.6 & & $1.2-29.9 \mathrm{ng} / \mathrm{mL}$ \\
Urinary cortisol (volume - & 18.8 & & $36-137 \mathrm{ug} / \mathrm{day}$ \\
$1200 \mathrm{~mL} /$ day) & & & \\
\hline
\end{tabular}

DHEA-S: dehydroepiandrosterone sulfate; 17-OHP: 17-hydroxyprogesterone; FSH: follicle stimulating hormone; LH: luteinizing hormone.

Table 2. Tetracosactin test

\begin{tabular}{lcc}
\hline & $\mathbf{0}^{\prime}$ & $\mathbf{6 0}^{\prime}$ \\
\hline $17-\mathrm{OHP}(\mathrm{ng} / \mathrm{mL})$ & 10.7 & 12.5 \\
Cortisol $(\mu \mathrm{g} / \mathrm{dL})$ & 14.3 & 35.2 \\
\hline
\end{tabular}

17-OHP: 17-hydroxyprogesterone. 
Serum tumour marker (CAl25, CA19.9, and $\alpha$-FP) levels were within the normal range. Chest $\mathrm{X}$-ray and EKG detected no abnormalities.

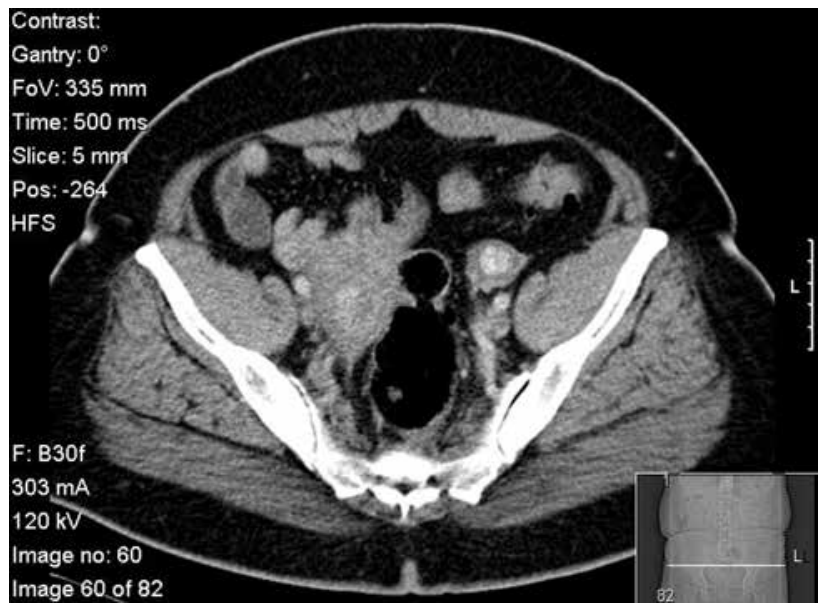

Figure 1. CT scan shows a 16-mm enhancing nodule on the left ovary.
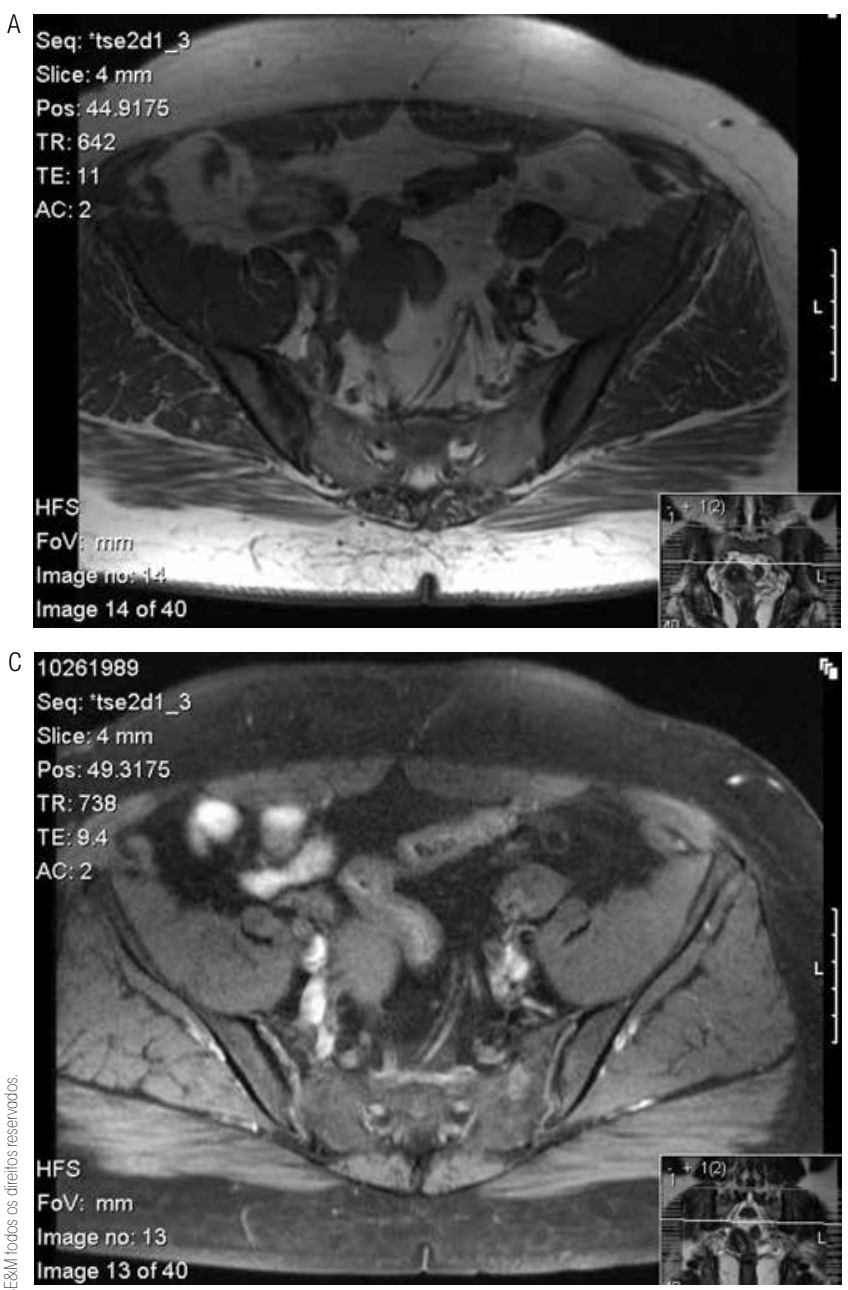

A diagnostic laparoscopy was proposed. The uterus was normal, as well as the right ovary. The left ovary was slightly enlarged. There were no adhesions, ascites, or any evidence of disseminated disease. Bilateral laparoscopic oophorectomy was performed, as previously discussed with the patient.

The histopathologic examination showed, in the left ovary, a tumour composed of large polygonal lutein-type cells that proliferated diffusely or were arranged in cords or nests. The stroma was usually sparse, sometimes hyalinized; mitoses were uncommon. It was also possible to see corpus albicans in the remaining ovarian tissue. The diagnosis was determined as stromal luteoma. Peritoneal washing and diaphragmatic cytology were negative.

There were no postoperative complications. Two months after surgery, androgen levels had normalized, including 17-OHP (Table 1). The patient maintained hypertension after surgery. Six months later, hirsutism had improved significantly (score 3, Ferriman-Gallwey scale).

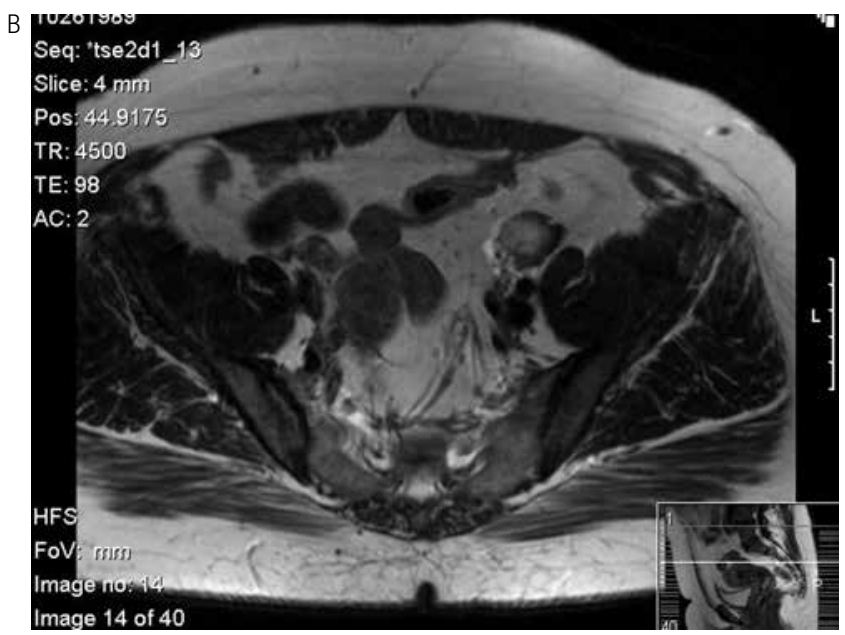

Figure 2. (A) Axial T1-weighted MR image shows a well-defined, ovoid solid mass with low signal intensity. (B) Axial T2-weighted MR image shows the mass with high signal intensity. (C, D) fat-suppressed T1-weighted image before and after gadolinium injection demonstrates the mass is well-enhanced. 


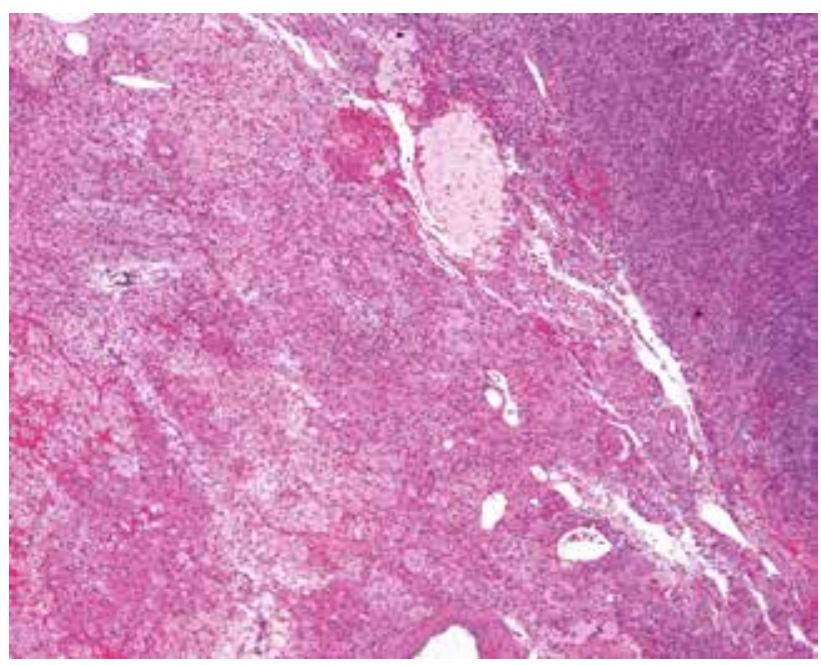

Figure 3. Stromal luteoma and adjacent ovarian parenchyma.

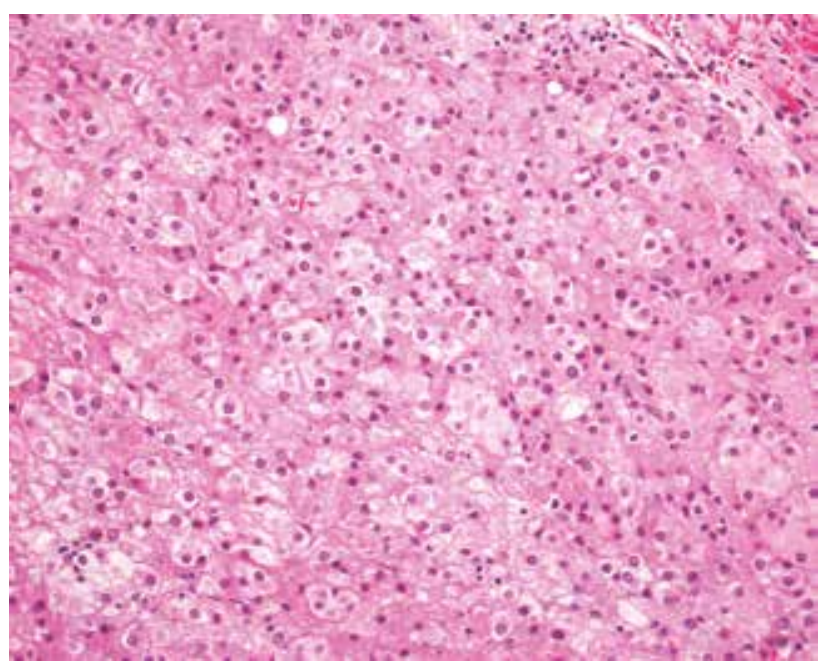

Figure 4. The tumour is composed of uniform polygonal cells with eosinophilic cytoplasm. Reinke's Crystals were not identified.

\section{DISCUSSION}

Whenever there is a rapid onset of androgenic symptoms and signs of virilisation, an adrenal or ovarian androgen-secreting tumour should be suspected (6). Clinical presentation of an ovarian virilising tumour may take many forms, including abdominal pain, bloating or distension. However, the most noticeable presentations are those associated with hormonal activity and virilising properties of the tumour (7). Signs and symptoms of virilising tumours usually take place in two definite phases, an early phase of defeminisation, and a subsequent phase of masculinization. Typically, a menstruating female will first notice oligomenorrhea or amenorrhea. There is regression of the breasts and external genitalia, atrophy of the uterus and adnexa, and loss of the female body contour. This is followed by hirsutism, acne, clitoral enlargement, increased libido, sterility, enlargement of the larynx, deepening of the voice, and temporal alopecia (8). On the other hand, some of these tumours have little or no androgenic activity and may, in fact, have estrogenic effects (8).

Our patient had worsening hirsutism and developed signs of virilisation, such as androgenetic alopecia, breast atrophy and deepened voice, six months before diagnosis.

Although testosterone levels above $200 \mathrm{ng} / \mathrm{dL}$ raise the suspicion of an androgen-producing tumour, 20\% of patients fail to reach this level (6). Detecting the source of an androgen-producing tumour is an exclusion process. DHEA-S levels above $700 \mathrm{ng} / \mathrm{dL}$ should raise the suspicion of an adrenal source.

In this case, high free and total serum testosterone with normal DHEA-S pointed out the presence of an ovarian virilising neoplasm. Our patient also revealed an elevation of the 17-OHP serum levels, and the tetracosactin test confirmed a deficiency in 21-hydroxylase. A difference was noted in basal 17-OHP level between the measure in the first month and the one carried out 2 months later (initial - $3.42 \mathrm{ng} / \mathrm{mL}, 2$ months later - $10.7 \mathrm{ng} / \mathrm{mL}$ ).

The normalization of 17-OHP after oophorectomy suggests a case of intratumoral 21-hydroxylase deficiency. Biochemical evidence for partial 21-hydroxylase deficiency is a common finding in patients with an adrenal incidentaloma, even in the absence of a congenital adrenal hyperplasia history (9). A case of a virilising tumour in a 6 year old girl with high levels of 17OHP that normalized after tumour resection was previously reported (9). To our knowledge, this is the first description of an ovarian intratumoral 21-hydroxylase deficiency in a postmenopausal woman.

The diagnosis of virilising tumours of the ovary is often difficult and challenging, especially when dealing with small tumours, not detectable by gynaecological examination. In a woman with signs of virilisation, it is essential to perform a careful gynaecological examination, measure serum androgens, and perform pelvic and abdominal CT scan to exclude an ovarian or adrenal androgen-producing tumour. Nevertheless, transvaginal ultrasound is the most sensitive method for the detection of ovarian tumours. However, the accuracy of the ultrasound examination is always dependent on the skill of the sonographer and the quality of the equipment.

Virilising ovary tumours are primarily treated surgically and have a generally good prognosis.

Disclosure: no potential conflict of interest relevant to this article was reported. 


\section{REFERENCES}

1. Stegner $\mathrm{HE}$, Loning T. [Endocrine-active tumors of the ovary]. Pathologe. 2003;24(4):314-22.

2. Takemori M, Nishimura R, Hasegawa K. Ovarian thecoma with ascites and high serum levels of CA125. Arch Gynecol Obstet. 2000;264(1):42-4.

3. Mehdi G, Ansari HA, Sherwani RK, Rahman K, Akhtar N. Ovarian steroid cell tumour: correlation of histopathology with clinicopathologic features. Patholog Res Int. 2011: p. 987895.

4. Roth LM, Czernobilsky B. Perspectives on pure ovarian stromal neoplasms and tumor-like proliferations of the ovarian stroma. Am J Surg Pathol. 2011;35(3):e15-33.
5. Shenker Y, Shenker Y, Malozowski SN, Ayers J, Grekin RJ, Barkan AL. Steroid secretion by a virilizing lipoid cell ovarian tumor: origins of dehydroepiandrosterone sulfate. Obstet Gynecol. 1989;74(3 Pt 2):502-6.

6. David G, Garder DS, ed. Greenspan's basic \& clinical endocrinology. 8.ed., Mc Graw Hill. 2007. p. 534.

7. Wang PH, Chao HT, Lee RC, Lai CR, Lee WL, Kwok CF, et al. Steroid cell tumors of the ovary: clinical, ultrasonic, and MRI diagnosis--a case report. Eur J Radiol. 1998;26(3):269-73.

8. Salim S, Shantha GPS, Patel AD, Kumar AA, Ganeshram P, Mehra $\mathrm{N}$, et al. Virilizing ovarian steroid cell tumor in a 40 year old South Indian female: a case report. Cases J. 2009;2:7521.

9. Snyder $D$, LaFranchi $S$. Severe virilization in a girl with a steroid cell tumor of the ovary. J Pediatr Endocrinol Metab. 1999;12(2):221-4. 